\title{
牛の乳歯々根吸收に関する生化学的研究
}

I. コラゲナーゼ活性について

\author{
森田英 夫 \\ 東京医科歯科大学歯学部小児歯科学教室（指導 山下 浩教授） \\ 東京医科歯科大学歯学部生化学教室（指導 佐々木哲教授）
}

(昭和 44 年 4 月 15 日受付)

\section{Collagenolytic Activity during Root Resorption of Bovine Deciduous Tooth}

\author{
Hideo Morita \\ Department of Pedodontics, School of Dentistry, Tokyo Medical and Dental \\ University (Director: Prof. Hiroshi Yamashita) \\ Department of Biochemistry, School of Dentistry, Tokyo Medical and \\ Dental University (Director: Prof. Satoshi Sasaki)
}

要旨 : 歯根吸収の現象を生化学的に説明する一つの手段として, 乳歯々質の有機質の主成分である コラーゲンの溶解現象に着目し, 牛の歯根吸収組織のコラーゲナーゼ活性の検出を試み, 同時に本組 織の組織学的所見も併せて検索した。また, 牛の永久前歯の研磨切片にこの吸収組織を直接載せて培 養することにより, in vitro における本組織の歯質溶解能についても検討を加えた。

実験に用いた材料は, 屠殺場で得た牛の下顎で, その吸収組織は肉眼的には乳歯を抜去した後に, 永久歯々胚との間に赤い組織として認められ, この時期のものの組織学的所見は, 歯根の吸収面に多 くの破歯細胞による吸収窩が認められた。乳歯々根からはがした吸収組織の組織学的所見は, 乳歯に 接していた表層部にはかなり多くの破歯細胞が認められ，その下層は血管に富む結合組織で，さらに 深層の部位では線維性組織が認められたが，破歯細胞は全く認められなかつた。

酵素活性を調べるために, 歯根が約 $1 / 3$ 程度吸収している乳歯を抜去後, 吸収組織を切り取りコラ ーゲンプレート法により，活性の有無を検討した。この吸収組織を直ちに抗生物質入りのタイロード 液に浸して滅菌後, 約 $1 \times 1 \mathrm{~mm}$ に細切し, この組織片をコラーゲンゲルの上に 置き, $37^{\circ} \mathrm{C}$ の恒温 器中で静置培養したところ，破歯細胞を含み血管に富む表層の組織はコラーゲンゲルを溶解したが， 深層の血管を含まない組織では，コラーゲンゲルの溶解は認められなかつた。また，コラーゲンゲ ルの溶解の起つたものの培養後の組織学的所見では，巨細胞を中心とした広範囲な線維の破壊が見ら れ，はつきりと組織の構造の維持されていないことが認められたが，培養してもコラーゲンゲルの溶 解の見られなかつたものでは, 巨細胞は認められず，組織の構造が比較的よく維持されていた。

また, 永久前歯切片に直接, 吸収組織を載せて培養し, in vitro における本組織の歯質溶解能を調 ベたところ，この組織が歯質を溶解する能力をもつような所見が認められた。

\section{緒言}

歯根が吸収されて乳歯が脱落し，やがて 永久歯
と交換する際に，永久歯々胚の 萠出路に相当する 部位の組織は,歯胚の発育による刺激を受けて,い わゆる吸収組織 11 に変化する。そしてこの吸収組 
織中の巨細胞（破歯細胞）が，萠出路に当る乳歯 の組織を硬軟に拘らず溶解するものと考えられて いる。

この吸収組織についての記載は古くからあり, 本組織の由来についても, 乳歯の歯髄が 吸収組織 に変化する, 乳歯の歯根膜が吸収組織になる, あ

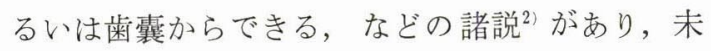
だ定説はない。

このように乳歯々根の吸収に関する組織学的研 究は古くから多数行なわれており, 最近では電子 顕微鏡による研究により, 乳歯と破歯細胞との関 係について詳細に述べられている ${ }^{3)}$ 。また，骨の 吸収と破骨細胞との関係についても多くの電顕に よる報告 ${ }^{4)}$ ) がある。組織学的所見はこのように充 実したにも拘らず, 乳歯々根の吸收を行なら組織 に関する生化学的研究は未だない。

歯根吸収に際しては, 歯質のミネラルと有機基 質の溶解を考え衫ばならないが，歯根吸収の現象 を生化学的に説明する一つの手段として, まず, 乳歯々質の有機質の主成分であるコラーゲンの溶 解現象に着目乙, 牛の歯根吸収組織のコラゲナー ゼ活性の検出を試み, 同時に本組織の 組織学的所 見も併せて検索した。また，永久前歯の研磨切片 にこの吸収組織を直接載せて培養することによ り, in vitroにおける本組織の歯質溶解能につい ても検討を加えた。

\section{実験材料と方法}

\section{1) 実験材料}

屠殺場より氷冷して持ち帰つた屠殺直後の生後 約 1 年の牛の下頭骨前端部をアルコールで清拭 後, 唇側の歯肉と骨壁を除去し, 歯根が約 $1 / 3$ 程度

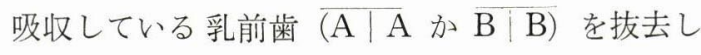
て, 吸収組織を採取した（図 1, 2)。これを直ち に，ペニシリン，ストレプトマイシンおよびマイ コスタチンをそれぞれ 1000 単位 $/ \mathrm{ml}$ 含む培養液に 浸して滅菌後, 約 $1 \times 1 \mathrm{~mm}$ の組織片とした。

2) コラーゲンおよび培地の調製

使用したコラーゲンは, Kang らの方法 ${ }^{6)} に よ$ り, ネズミの皮膚から中性塩可溶性コラーゲンを

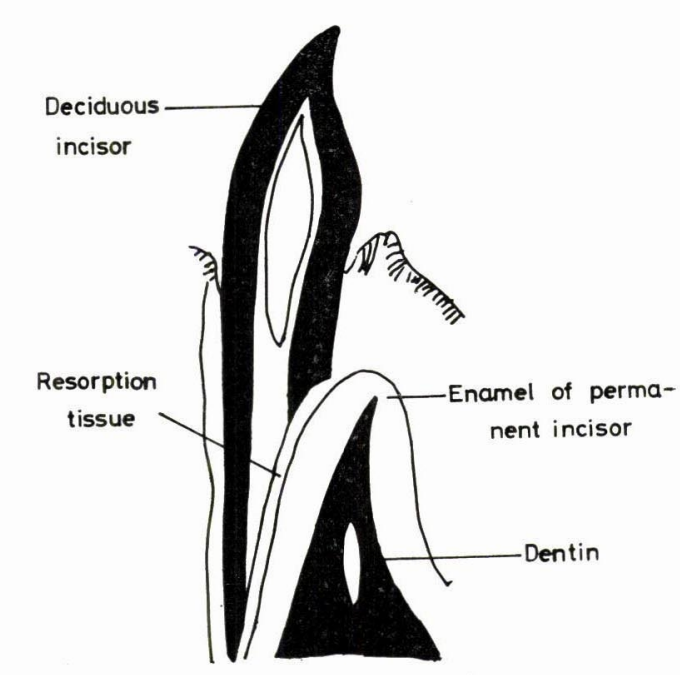

図 1 歯根の吸収状態と吸収組織との関倸

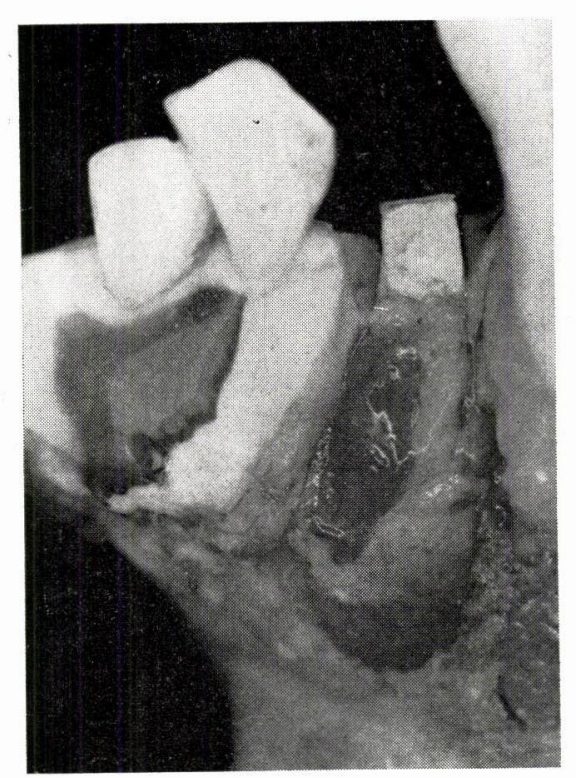

図 2 吸収組織の肉眼的所見

乳歯を抜去した後に永久歯々胚との間に 認められる。

調製した。このコラーゲンを約 $4{ }^{\circ} \mathrm{C}$ の冷燐酸緩 衝液（pH 7.4）に約 $0.2 \%$ になるように溶解した 後, $0.4 \mathrm{M} \mathrm{NaCl}$ に対して 2 日間透析し， 1,5000 $\mathrm{rpm}$ で 1 時間遠心し，その上清を用いた。

培地には Tyrode 溶液を Eagle 培地用 ${ }^{8)}$ のミ ノ酸混液, グルタミン酸溶液, ビタミン混液, ペ 
ニシリン，ストレプトマイシン混液で補強し，ミ リポアフィルターで濾過して滅菌したものを用い た。

3）培養方法

Gross らの方法 ${ }^{7)}$ に従い，プラスチック製の培養 且に、コラーゲン溶液と培養液を $1 ： 3$ に混合し た溶液を入れてカバーグラスで被い，培地が乾燥 しないように水を張ったシャーレの中で $37^{\circ} \mathrm{C}, 12$ 時間保ち、コラーゲンをゲル化させた後に 組織片 をこのゲルの上に置き, $37^{\circ} \mathrm{C}$ で培養した(図 3 )。

また, in vitro における吸収組織の歯質溶解能 を調べるために，培地上に屠殺直後の牛の下顎永 久前歯の研磨切片を置き，この上に吸収組織の表

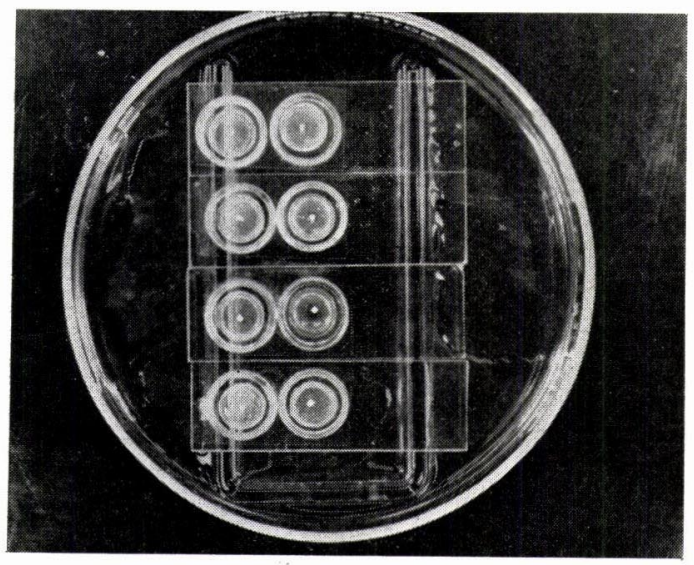

図 3 培養装置

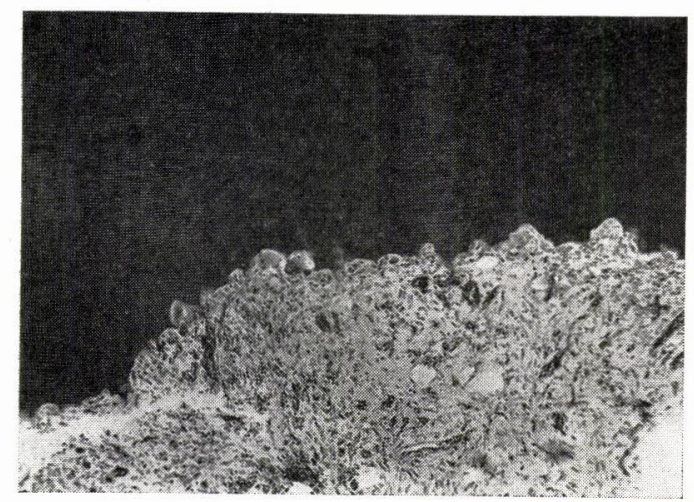

a. 歯根の吸収面に多くの破歯細胞による吸収窩 が認められる。へマトキシリンエオジン染色 $\times 80$
層部が歯面に接するように載せ，同様に培養し た。

4) 組織学的方法

培養前と培養後の吸収組織を $10 \%$ 中性ホルマリ ンで固定し, 通法に従い， ヘマトキシリンエオジ ン染色を行なつた。

\section{結果}

1）培養前の採取した吸収組織の所見

歯根が約 $1 / 3$ 吸収している時期（図 1,2 ）の歯 質表面と吸収組織は図 4 の如くで, 歯根の吸収面 に多くの破歯細胞による吸収窩が認められる。

乳歯々根からはがした吸収組織は三層から成り (図 5 ), 乳歯に接していた表層部にはかなり多く の破歯細胞が認められ，その下層は血管に富む結 合組織で, さらに哚層の部位では線維性組織が認 められたが，破歯細胞は全く認められなかつた。

2 ) 吸収組織のコラーゲンゲル溶解能

コラーゲンゲル上での 培養により, 組織のコラ ゲナーゼ活性の有無を検討したところ，培養組織 周辺に明らかなコラーゲンゲルの溶解が，ゲルの 透明化として認められた。図 6 は吸収組織を $37^{\circ} \mathrm{C}$ で 2 日間培養した例で, 左側のリングは血管に富 むごく表層の組織で, 組織培養周囲のコラーゲン ゲルが明らかに溶解しているのが認められる。右 側のリングはより深層の血管をあまり含まない組

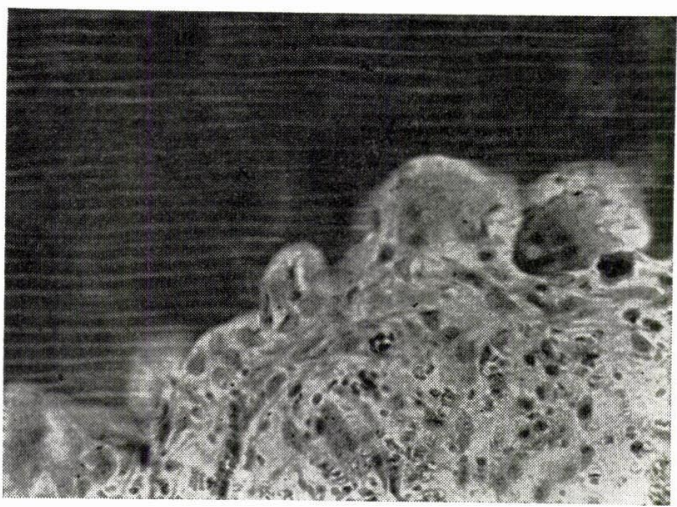

b. 図 4 a の一部桩大 H-E 染色 $\times 350$

図 4 吸収組織と歯根の吸収面 


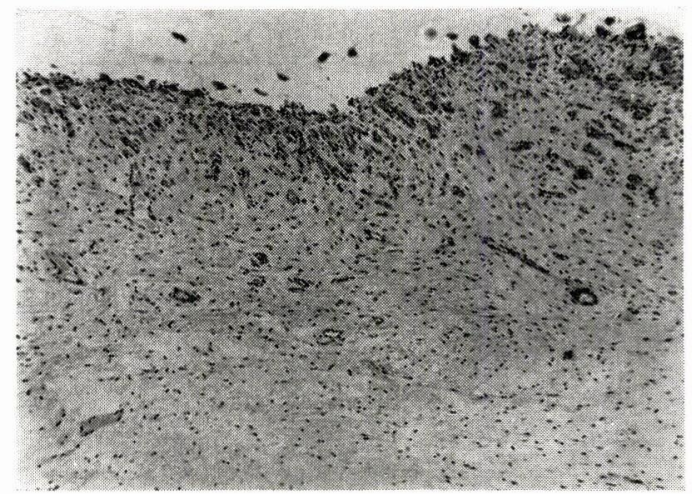

a. 乳歯々根からはがした吸収組織の全景。へマ トキシリンエオジン染色 $\times 80$

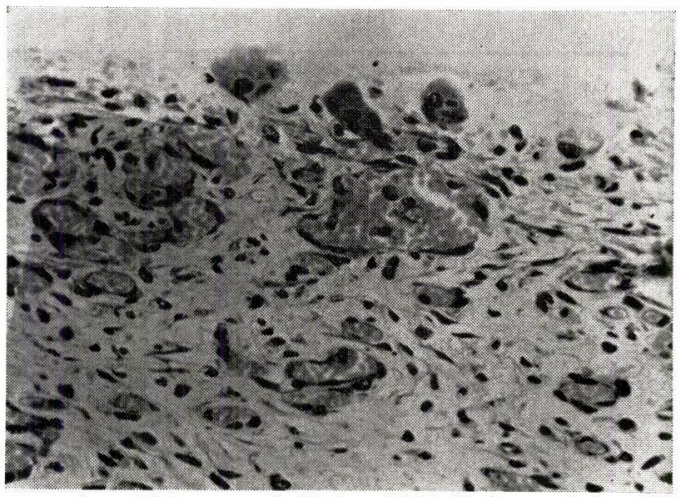

b. 図 5 a の一部拡大 $\mathrm{H}-\mathrm{E}$ 染色 $\times 350$ 乳歯に接していた表層部には多数の破歯細胞 が認められる。

図 5 吸収組織の詳細

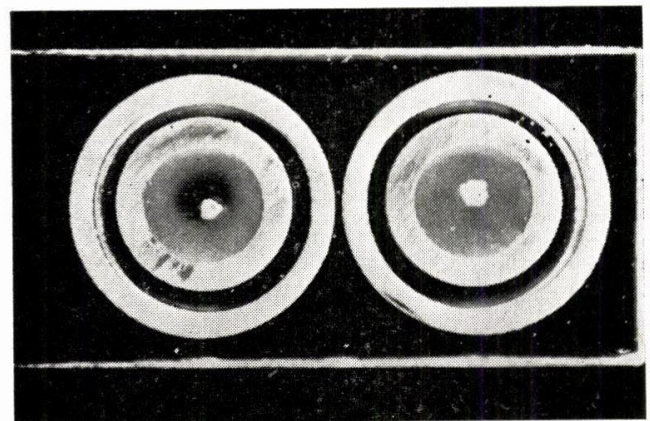

図 6 培養 3 日目, 組織培養周囲のコラーゲンゲ ルの溶解が認められる。

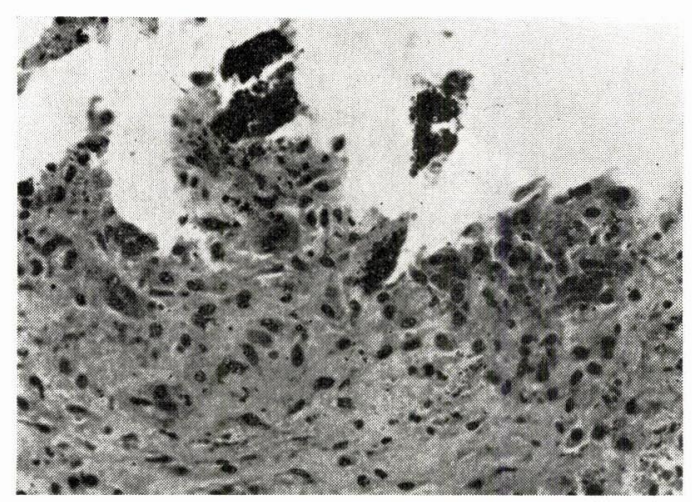

図 8 培養してコラーゲンゲルの溶解の起つた 吸収組織像で, 破歯細胞が認められ, は つきりと組織の構造が維持されていない。 ヘマトキシリンエオジン染色 $\times 300$

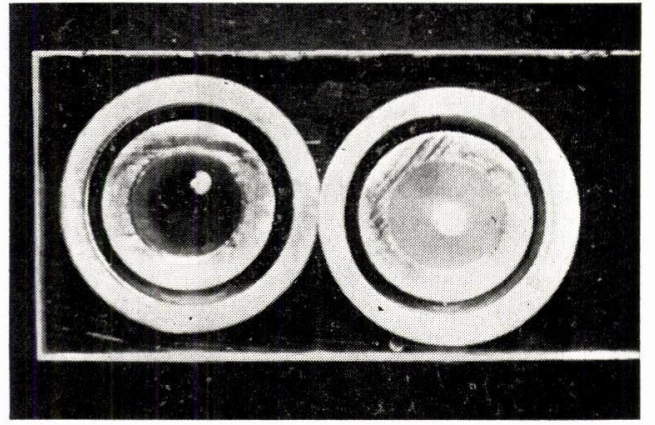

図 7 培養 4 日目, より広範囲なコラーゲンゲル の溶解が認められる。

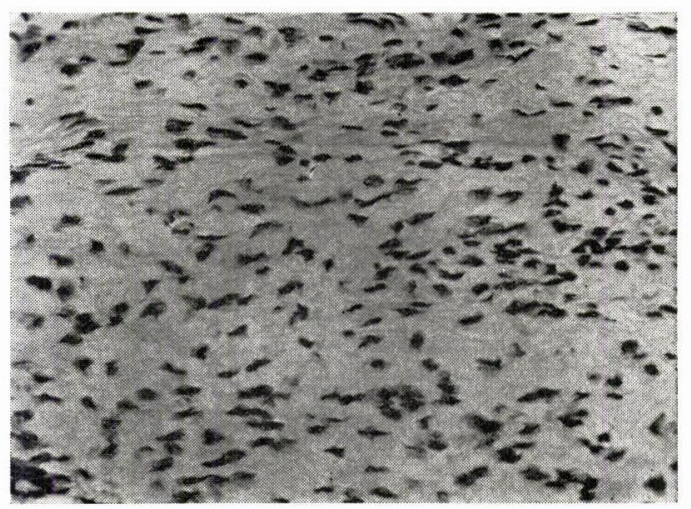

図 9 培養してもコラーゲンゲルの溶解の見ら れなかつた吸収組織像で, 破歯細胞は認 められない。 ヘマトキシリンエオジン染色 $\times 300$ 
表 1 吸収組織によるコラーゲンゲルの溶解の頻度

\begin{tabular}{|c|c|c|c|c|c|c|c|}
\hline 例 数 & 組 織 別* & 培養 1 日目 & 2 日目 & 3 日目 & 4 日 目 & 5 & 日 目 \\
\hline 1 & 表層 & - & m & | ホルマリンで & & & \\
\hline 2 & " & - & $H$ & \}固定，検鏡 & & & \\
\hline 3 & " & - & + & m & ）ホルマリンで & & \\
\hline 4 & " & - & \pm & $H$ & (3) & & \\
\hline 5 & $\prime \prime$ & - & \pm & H & ＼cjkstart固定，検鏡 & & \\
\hline 6 & $\prime \prime$ & - & - & + & H & & 世 \\
\hline 7 & $\prime \prime$ & - & - & + & H & & 册 \\
\hline 8 & $\prime \prime$ & - & \pm & \pm & \pm & & \pm \\
\hline 9 & $\prime \prime$ & - & - & - & - & & - \\
\hline 10 & $\prime \prime$ & - & + & H & H & & 册 \\
\hline 11 & " & - & - & - & - & & - \\
\hline 12 & $\prime \prime$ & - & - & - & - & & - \\
\hline 13 & " & - & - & \pm & H & & HI \\
\hline 14 & $\prime \prime$ & - & - & - & - & & - \\
\hline 15 & $\prime \prime$ & - & - & - & + & & WH \\
\hline 16 & " & - & - & - & - & & - \\
\hline 17 & "I & - & - & + & $H$ & & 世 \\
\hline 18 & 深層 & - & - & - & ) ホルマリンで & & \\
\hline 19 & " & - & - & - & ? & & \\
\hline 20 & " & - & - & - & )固定，検鏡 & & \\
\hline 21 & " & - & - & - & - & & - \\
\hline 22 & " & - & - & - & - & & - \\
\hline 23 & " & - & - & - & - & & - \\
\hline 24 & " & - & - & - & - & & - \\
\hline 25 & " & - & - & - & - & & - \\
\hline 26 & "1 & - & - & - & - & & - \\
\hline 27 & "1 & - & - & - & - & & - \\
\hline 28 & "1 & - & - & - & - & & - \\
\hline 29 & " & - & - & - & - & & - \\
\hline 30 & $\prime \prime$ & - & - & - & - & & - \\
\hline
\end{tabular}

* : 表層は血管に富む表層の組織, 深層は血管をあまり含まない深層の組織

一 : 組織培養周囲のコラーゲンゲルの溶解の認められないもの

士 : 溶解の判然としないもの

$+:$ 組織周囲が約 $1 \mathrm{~mm}$ 透明になつているもの

H : 組織周囲が約 $2 \mathrm{~mm}$ 透明になつているもの

m : 組織周囲が約 $3 \mathrm{~mm}$ 透明になつているもの

卅 : 全体が溶解しているもの

織を培養した例で，コラーゲンゲルの溶解は全く 認められなかつた。図 7 は $37^{\circ} \mathrm{C}$ で 3 日間培養し た例で，より広範囲なコラーゲンゲルの溶解が認 められた。

このコラーゲンゲルの溶解の頻度を，血管に富 むごく表層の組織とあまり血管を含まない深層の
組織とについて比較したところ（表 1 )，血管に富 む組織17例中，その約 $65 \% に$ 当る11例にコラーゲ ンゲルの溶解が認められたが，血管をあまり含ま ない組織では，1例もコラーゲンゲルの溶解は認 められなかつた。また，このコラーゲンゲルの溶 解は, 培養後 1 日目では全例において認められな 


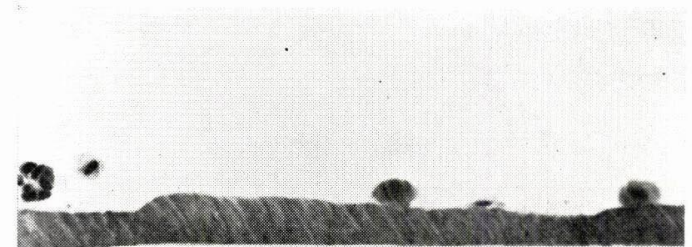

図 10 in vitroにおける吸収組織の歯質に対 する溶解能, 破歯細胞が歯質表面に密 着している。 ヘマトキシリンエオジン染色 $\times 350$

かつたが，2 日目に現われはじめ，5 日目頃には 溶解のあつたゲルは全体が溶解して透明になつ た。

3 ) 培養後の吸収組織の所見

$37^{\circ} \mathrm{C}$ で 3 日間培養してコラーゲンゲルの溶解 の起つた組織の所見は図 8 の如くで, 培養前のそ れと比較すると巨細胞を中心とした広範囲な線維 の破壊が見られ，はつきりと組織の構造の維持さ れていないことが認められた。

図 9 は，培養してもコラーゲンゲルの溶解の見 られなかつた組織像で, 巨細胞は認められず, 線 維の破壊も見られず, 組織の構造が比較的よく維 持されている。

4) in vitro における吸収組織の歯質に対する 溶解能

コラーゲンをゲル状にした培地に，牛の永久前 歯象牙質の研磨切片（厚さ約 $100 \mu$ ) を置き，その 上に血管に富む吸収組織の表層部を載せて $37^{\circ} \mathrm{C}$ で 4 日間培養したところ, 吸収組織は歯質に密着 し，組織が歯質を溶解している所見が認められた (図10)。しかし，in vivoにおけるような著明な 吸収窩の形成にまでは至っていない。

\section{考察}

本研究で歯根吸収組織のコラーゲン 分解酵素活 性の検出に用いたコラーゲンを含む培地による培
養法は, Gross $ら^{7 !}$ の発案によるもので, 可溶性コ ラーゲンをゲル状にした培地にはアミノ酸やビタ ミンなどの栄養源を含み，この上で組織を培養し て培地中のコラーゲンゲルが溶解して透明になれ ば，組織にコラーゲン分解活性のあることが証明 される。このゲルは通常の蛋白分解酵素, 例え ば，トリプシンやカテプシンなどでは溶解されな い。

乳歯々根が肉芽様の absorbent organによって 吸収されることを，1859年に Tomes，J. が最初 に報告して以来，Hopewell-Smith ${ }^{11}$ は乳歯々根吸 収時の人およびネコの肉芽組織について詳述して おり，Sognnaes ${ }^{9)}$ 歯の吸収には，血管に富む肉 芽組織の存在が必須であると述べている。

牛でも乳歯々根の活発に起つている時期（図 1, 2 ) の吸収組織は肉眼的に, 乳歯々根の吸収面に 対応した歯導帯 gubernacular cord ${ }^{10)}$ 上に常に赤 い組織として認められた。この組織は三層から成 り（図 5 ), 血管に富む組織は 乳歯々根の吸収面 に接した吸収組織の表層部に存在し，破歯細胞も この部位にのみ認められる。そして,この組織の 表層の血管に富む部位からのみ活性が検出された (図 6,7 )。

さらに,このコラーゲンゲルの溶解の起つた組 織像（図 8 ）を，培養してもコラーゲンゲルの溶 解の見られなかつたもの（図 9 ) と比較すると, 破歯細胞を中心とした広範囲な線維の破壊が見ら れ，はつきりと組織の構造の維持されていないこ とから，歯質のコラーゲン線維を溶解する酵素 は, 破歯細胞を含む吸収組織から放出されてい て，これがコラーゲンを分解しているものと考え られる。

動物の組織を構成するコラーゲンは，生理的改 造の起る際に消失することが知られており, 特 にオタマジャクシの変態時の尾 ${ }^{7111}$, 分婏後の子 宮 ${ }^{12)}$, 実験的肝硬変症の治癒期の肝臟 ${ }^{13)}$, 人の皮膚 14) や歯肉 ${ }^{15)}$ などにコラーゲン 分解活性のあること が認められており, 部分的にはその酵素の性質も 知られてきている16)。

今のところ，歯根吸収組織からこのような組 
織のコラーゲン分解酵素が作られ，乳歯のコラー ゲンを分解しているとは，組織からコラーゲン分 解酵素が分離精製されていないので断言はできな い。しかし，このコラーゲン分解酵素が 分離精製 されて，その性質が明らかになれば，乳歯々根吸 収時のコラーゲンの分解消失についての 問題も明 らかにされるに違いない。

吸収組織を永久前歯の研磨切片上に直接載せて 培養し，この組織の in vitroにおける歯質溶解能 を追究したところ，この組織が歯質を溶解する能 力をもつように見えた (図10)。in vivo で見られ るような明らかな吸収窩はこの所見で認められな かつたが，これは培養期間の短いこと（4 日間） や環境の変化（in vitro）などが原因しているもの と思われる。

そこで，この in vitro の所見を基に生理的な歯 質の吸収過程を類推してみると，まず吸収組織に 血管が密に分布して破歯細胞が現れる。吸収組織 の表面に血管が密に分布しているのは，これらの 血管が栄養血管として付近にある破歯細胞に物質 代謝に必要な物質や酸素を供給して, 細胞内の代 謝活動を活発にするためと思われる。Furseth ${ }^{3)}$ も 電子顕微鏡による所見から，破歯細胞中に細胞の エネルギー産生に必須であるミトコンドリアが多 く存在し，この細胞の代謝活性が盛んであろうこ とを推論している。本所見でも，このような細胞 がコラーゲン分解酵素や歯質のミネラルを溶解す る物質を分泌して，歯質を溶解しやがて著明な吸 収窩を形成しつつ，歯質を溶解して行くのではな いかと思われる。

このように破歯細胞が歯質を溶解吸収するとい う考えは古くから多くの人達に支持されてきた。 しかし, 形成細胞, 多核白血球, 形質球などが役 割を演ずる osteolysis によっても吸収の起る゙こ とが知られているので，歯根吸収の問題をさらに 究明するためには, 生化学的ならびに 組織化学的 所見の集積が望ましい。今後は本組織から破歯細 胞のみを集めて，この細胞から直接コラーゲン分 解酵素を証明すると共に, 細胞の歯のミネラルに 対する溶解能も明らかにされれば，生理的歯根吸
収の機構を解明する上の重要なデータが得られる ものと思われる。

\section{総括}

1. 歯根吸収の現象を生化学的に説明する一つ の手段として，乳歯々質のコラーゲンの溶解に着 目し, 生後約 1 年の牛の吸収組織のコラゲナーゼ 活性の検出を試みた。

2.コラーゲンゲル平板法により吸収組織のコ ラゲナーゼ活性を測定したところ，歯質の吸収面 に対応した血管に富み破歯細胞を含むごく表層の 組織からのみ，コラーゲンゲルの溶解能が認めら れた。

3. 組織学的には，破歯細胞はこの 血管に富む 表層の組織にのみ存在し，また培養してコラーゲ ンゲルの溶解の起つた組織像では，破歯細胞を中 心とした広範囲な線維の破壊が見られ，はつきり と組織の構造の維持されていないことが認められ た。

4.これらのことから，歯質のコラーゲン線維 を溶解する酵素は，破歯細胞を含む組織から放出 されていて，これが乳歯のコラーゲンを分解して いるものと考えられる。

5. また，永久前歯切片に值接，吸収組織を載 せ 4 日間培養して，in vitroにおける本組織の歯 質溶解能を調べたところ，この組織が歯質を溶解 する能力をもつような所見が認められた。

稿を終るにあたり，終始愁切な御指導と御校閲をいた だいた山下浩教授ならびに佐々木哲教授に心から感謝致 します。また，組織培養法を御教示，御指導下さいまし た本学歯学部生化学教室清水正春助教授, 組織学的技術 を提供していただいた本学歯学部口腔病理学教室小守昭 助教授および東京歯科大学病理学教室吉木周作講師に厚 くお礼申し上げます。最後に，御協力をいただきました 生化学教室および 小児歯科学教室の皆様に 感謝致しま す。

\section{文献}

1) Hopewell-Smith, A. : The process of osteolysis and odontolysis, or so-called "absorption" of calcified tissues: A new and original investigation, Dental Cosmos, 72 : 462, 912, 
1036, 1151, 1930.

2) Treuenfels, P.: Mikroskopische Untersuchungen über die Resorption der Milchzähne, Dtsch. Mschr. Zahnheilk., 19: 193, 1901.

3) Furseth, R.: The resorption processes of human deciduous teeth studied by light microscopy, microradiography, and electron microscopy, Archs oral Biol., $13:$ 417, 1968.

4) Hancox, N. M. and Boothroyd, B. : Structure-function relationships in the osteoclast, from "Mechanisms of hard tissue destruction", edited by Sognnaes, R. F., Washington, 1963, Am. Ass. Advanc. Sci., p. 497.

5) Greulich, R. C. : Organic mass distribution in bone matrix undergoing osteoclastic resorption, Archs oral Biol., $3: 137,1961$.

6) Kang, A. H., Nagai, Y., Piez, K. A. and Gross, J. : Studies on the structure of collagen utilizing a collagenolytic enzyme from tadpole, Biochemistry, 5:509, 1966.

7) Gross, J. and Lapiere, C. M. : Collagenolytic activity in amphibian tissues: A tissue culture assay, Proc. N. A. S., $48: 1014,1962$.

8) Merchant, D. J., Kahn, R. H. and Murphy, W. H. : Handbook of cell and organ culture, Minneapolis, 1967, Burgess Publishing Company, p. 227.

9) Sognnaes, R. F. : Microstructure and histochemical characteristics of the mineralized tissues, Ann. N. Y. Acad. Sci., 60 : 5, 545,
1955.

10) Scott, J. H. : The development and form of the human dentition in "Dento-facial development and growth" Pergamon, 1967, Pergamon Press, p. 7.

11) Lapiere, C. M. and Gross, J. : Animal collagenase and collagen metabolism, from "Mechanisms of hard tissue destruction", edited by Sognnaes, R. F., Washington, 1963, Am. Ass. Advanc. Sci., p. 663.

12) Morrione, T. G. and Seifter, S. : Alteration in the collagen content of the human uterus during pregnancy and post partum involution, J. Exptl. Med., 115 : 357, 1962.

13) Morrione, T. G. and Levine, J. : Collagenolytic activity and collagen resorption in experimental cirrhosis, Arch Path, 84: 59, 1967.

14) Eisen, A. Z., Jeffrey, J. J. and Gross, J. : Human skin collagenase. Isolation and mechanism of attack on the collagen molecule, Biochim. Biophys. Acta, 151 : 637, 1968.

15) Bennick, A. and Hunt, A. M. : Collagenolytic activity in oral tissues, Archs oral Biol., 12 : 1, 1967.

16) Gross, J. and Nagai, Y.: Specific degradation of the collagen molecule by tadpole collagenolytic enzyme, Proc. N. A. S. $54: 1197$, 1965. 